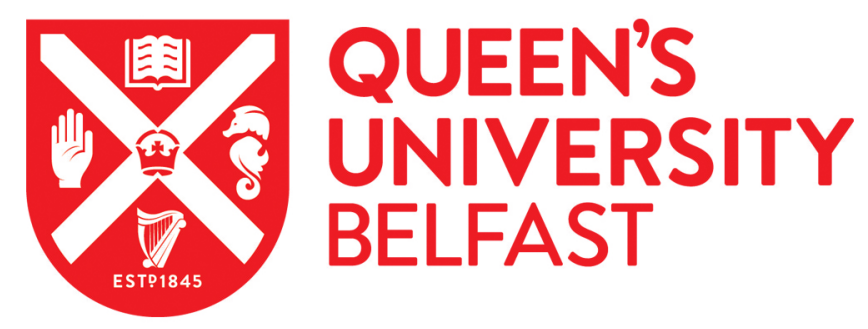

\title{
Water Dilutes and Alcohol Concentrates Urinary Arsenic Species When Food is the Dominant Source of Exposure
}

de Moraes, N. V., Carey, M., Neville, C. E., Cruise, S., McGuinness, B., Kee, F., Young, I. S., Woodside, J. V., \& Meharg, A. A. (2019). Water Dilutes and Alcohol Concentrates Urinary Arsenic Species When Food is the Dominant Source of Exposure. Exposure and Health. https://doi.org/10.1007/s12403-019-00329-5

Published in:

Exposure and Health

Document Version:

Peer reviewed version

Queen's University Belfast - Research Portal:

Link to publication record in Queen's University Belfast Research Portal

Publisher rights

C) 2019 Springer Nature B.V.

This work is made available online in accordance with the publisher's policies. Please refer to any applicable terms of use of the publisher.

\section{General rights}

Copyright for the publications made accessible via the Queen's University Belfast Research Portal is retained by the author(s) and / or other copyright owners and it is a condition of accessing these publications that users recognise and abide by the legal requirements associated with these rights.

Take down policy

The Research Portal is Queen's institutional repository that provides access to Queen's research output. Every effort has been made to ensure that content in the Research Portal does not infringe any person's rights, or applicable UK laws. If you discover content in the Research Portal that you believe breaches copyright or violates any law, please contact openaccess@qub.ac.uk. 
1 Water dilutes and alcohol concentrates urinary arsenic species when food is the

\section{2 dominant source of exposure}

4 Natalia V. de Moraes (0000-0002-4389-058X) ${ }^{1,3 *}$, Manus Carey ${ }^{1}$, Charlotte E Neville ${ }^{2}$, Sharon Cruise ${ }^{2}$, 5 Bernadette McGuinness ${ }^{2}$, Frank Kee ${ }^{2}$, Ian S Young ${ }^{2}$, Jayne V Woodside (0000-0002-5691-4659) $)^{1,2}$, 6 Andrew A. Meharg (0000-0003-2019-0449) ${ }^{2}$

${ }^{1}$ Institute for Global Food Security, Queen's University Belfast, 19 Chlorine Gardens, Belfast BT9 5DL, $9 \quad$ Northern Ireland, UK;

${ }^{2}$ Centre for Public Health, Queen's University Belfast, Northern Ireland, UK.

11

*Author for correspondence: Natália V de Moraes

E-mail: natalia.v.moraes@unesp.br

Department of Natural Products and Toxicology

School of Pharmaceutical Sciences, São Paulo State University (UNESP)

Rodovia Araraquara-Jaú, km 01, Araraquara, SP, Brazil, ZIP 14800-903

Phone: +551633014689 

38

We are grateful to all the participants of the Northern Ireland Cohort for the Longitudinal Study of Aging (NICOLA), and the whole NICOLA team, which includes nursing staff, research scientists, clerical staff, computer and laboratory technicians, managers and receptionists. The Atlantic Philanthropies, the Economic and Social Research Council, the UKCRC Centre of Excellence for Public Health Northern Ireland, the Centre for Ageing Research and Development in Ireland, the Office of the First Minister and Deputy First Minister, the Health and Social Care Research and Development Division of the Public Health Agency, the Wellcome Trust/Wolfson Foundation and Queen's University Belfast provide core financial support for NICOLA. The authors alone are responsible for the interpretation of the data and any views or opinions presented are solely those of the authors and do not necessarily represent those of the NICOLA Study team.

(1)

(1)

\section{7} (1) 


\section{Abstract}

Exposure to certain arsenic (As) species has been associated with increased cancer risk and a wide range of other health concerns, even at low levels. Here we used urine as a biomarker of As internal dose in a well characterised cohort to relate diet, demographics and geography to exposure. As speciation in spot urine samples was determined for 89 participants aged $\geq 50$ years from the Northern Ireland Cohort for the Longitudinal Study of Aging (NICOLA), stratified to cover the country. Principal component analysis showed that all As species clustered together, suggesting that arsenobetaine, inorganic As and the methylated species monomethylyarsonic acid and dimethylarsinic acid forms have a common source. Seafood and alcohol consumption were positively correlated with As species, while dairy products (i.e. milk) and tap water were negatively correlated. Multiple regression analysis showed that diet explained approximately $30 \%$ of the variability in urinary iAs concentrations. Geography was not found to be a predictor of As exposure. Dairy consumption was negatively correlated and the best predictor of iAs in urine, explaining $15.9 \%$ of the variability. The majority of the variation in As biomarkers was not explained, suggesting the contribution of other sources and other non-predicted variables on As metabolism and elimination.

Keywords: arsenic, diet, metabolism, speciation, urine.

\section{(1)}




\section{Introduction}

Human health is dependent on the quality of the food, air and water available. Long-term clinical health conditions (such as cardiovascular diseases, diabetes, neurodegenerative diseases, respiratory diseases and cancer) can be related to environmental and food exposure to toxic compounds (Wardrop and Le Blond 2015). In the case of the metalloid arsenic (As), high concentrations of As in drinking water are typically found in Bangladesh, West Bengal (India), Inner Mongolia (China), Taiwan, Argentina and Chile (Chappell et al. 2003; Wu et al. 2018). In these areas, it is well known from epidemiological studies that there is an association between inorganic As (iAs) exposure and urinary bladder, kidney and lung cancer risk (Chappell et al. 2003; IARC 2012). Although those naturally high As regions are of major concern, low-moderate chronic exposure to As have also been associated with a range of detrimental health effects, including an increased risk of skin lesions, diabetes, cardiovascular effects, neurotoxicity, lung disease, reproductive effects and cancer (WHO 2001).

Exposure to As can originate from different sources, such as inhalation (Xu et al. 2013; Subhani et al. 2015), dermal (Ouypornkochagorn and Feldmann 2010), drinking water (IARC 2004, Chappell et al. 2003; Navoni et al. 2014; Diaz et al. 2015) and food (Meharg and Raab 2010; Signes-Pastor et al. 2017a). The contribution of these sources depends on As levels in each of these matrices. Food can be considered the main source of As exposure in the European Union and many other regions, where there is high percentage of population with access to treated water supplies (Meharg and Raab 2010; SignesPastor et al. 2017a). Rice consumption has been shown to be a concern for iAs exposure as it accumulates iAs up to concentrations 10-fold higher than in other grains (Williams et al. 2006; Kordas et al. 2016; Davis et al. 2017). Dietary studies, using urine spot samples as a biomarker of As exposure, have shown that iAs in rice is both bioavailable and a dominant source in the diet (Signes-Pastor et al. 2017a; Wei et al. 2014). As species commonly found in urine include iAs, monomethylarsonic acid (MMA) and dimethylarsinic acid (DMA), both of which are human metabolites of iAs, and the nontoxic arsenobetaine (AsB), derived from seafoods (Navas-Acien et al. 2011; Popowich et al. 2016). Other dietary sources of As, and how general dietary patterns (liquid, alcohol and vitamin intake etc.) interplay with As metabolism, the methylation of iAs to MMA and DMA, are not well understood. 
This study has a developed country focus, Northern Ireland (NI), where a high percentage of people uses treated municipal water supplies with low levels of iAs (Signes-Pastor et al. 2017b) and where rice is not the dominant staple (Harrington et al. 2001). Here we evaluate the association between As exposure, nutrition and demographic variables in NI using a subset of participants aged $\geq 50$ years from the Northern Ireland Cohort for the Longitudinal Study of Ageing (NICOLA). The subset was considered of settled geography since all participants were living in their own homes in Northern Ireland. As has been shown to have strong environmental gradients in soils and waters over NI, as revealed through detailed sampling (at $2 \mathrm{~km}^{2}$ density) (GSNI 2007).

\section{Material and methods}

\subsection{Study Population}

This study was conducted in a sub-sample $(n=89)$ of participants from the NICOLA study who were also taking part in the NICOLA dietary validation study (NIDAS). Participants were randomly selected, aged $\geq 50$ years (born on or before September $30^{\text {th }} 1962$ ) and living in their own homes across NI. NIDAS was primarily conducted to validate the dietary assessment methodology used in the NICOLA study. Ethical approval for the both NICOLA and NIDAS studies were obtained from the School of Medicine, Dentistry and Biomedical Sciences Research Ethics Committee, Queen's University Belfast (Ethical Approval Numbers 15.18 and 12.23, respectively).

The inclusion criteria for this sub-sample were: a) participants in the NICOLA study; b) participants willing to allow a researcher to visit them at their home. The exclusion criteria were: a) participants unable to provide informed consent; b) participants with medical conditions that would limit their ability to complete the protocol. Each participant signed a written informed consent prior to participating in the study.

Spot urine samples were collected for As speciation analysis. All urine samples were stored at $-80{ }^{\circ} \mathrm{C}$ until analysis. All participants were asked to complete a 4-day food diary which involved them 
recording their food and drink intake over a period of four days (two weekdays and two weekend days).

The dietary assessment and urine sampling were repeated after a period of 6 months to allow the capture of any seasonal variation in diet. Demographic data (age, gender, location of residence, level of education, smoking status and alcohol consumption) were obtained via a computer assisted personal interview, while clinical data [weight, height, body mass index (BMI)] were obtained as part of the NICOLA health assessment (Neville et al. 2019).

\subsection{As speciation analysis and sample preparation}

iAs, MMA, DMA and AsB were analysed in urine by ion chromatography interfaced with inductively coupled plasma-mass spectrometry detection (IC-ICP-MS) using the method published by SignesPastor et al. (2017c). Briefly, chromatographic separation was performed using a Dionex IonPac ${ }^{\mathrm{TM}}$ AS7 RFIC analytical column $(2 \times 250 \mathrm{~mm}$, Thermo Scientific $)$ protected by a Dionex IonPac ${ }^{\mathrm{TM}}$ AG7 guard column $(2 \times 50 \mathrm{~mm}$, Thermo Scientific) and a 12.5-minutes gradient mobile phase starting from 100\% $20 \mathrm{mM}$ ammonium carbonate (A) up to $100 \% 200 \mathrm{mM}$ ammonium carbonate (B). Mobile phase flow rate was $0.3 \mathrm{~mL} / \mathrm{min}$. Certified standards of AsB, DMA, tetramethylarsonium (TMAO), MMA and iAs were used to determine their retention times. The concentration of As species were determined using a DMA dilution series. Seronorm ${ }^{\mathrm{TM}}$ Trace Elements Urine (Lot 0511545 , Sero ${ }^{\circledR}$ ) and Clinchek ${ }^{\circledR}$ Urine Control, for As species, level 1, were used as certified reference material (CRM) for quality control. Working standards, blank samples, urine samples and certified reference materials were included within each analytical run.

The urine samples were prepared by appropriate dilution and centrifuged at $4500 \times \mathrm{g}$ for 5 minutes. Supernatants were transferred to $700 \mu \mathrm{L}$ polypropylene vials with $1 \%$ analytical grade hydrogen peroxide $\left(30 \%\right.$, Analar Normapur $\left.{ }^{\circledR}\right)$ to convert all arsenite (AsIII) in arsenate (AsV). As species concentrations in urine were statistically modelled with and without normalization by specific gravity (SG). 
Participants recorded all food and drink consumed over 2 weekdays and 2 weekend days ( 4 consecutive days) by reporting the frequency, amount and method of food preparation. Amounts of foods were reported in household measures (for example, 1 table spoon) or natural measures (for example, 1 slice of bread). Researchers explained the dietary assessment protocols in detail to ensure close adherence. Completed food diaries were reviewed by the researchers in order to check if any entries were unclear and to clarify the information recorded. Mean food, energy and nutrient intakes from the food diaries were calculated using a computerised food analysis database (Nutritics 2018).

\subsection{Statistical analysis}

All statistical analysis was performed using SPSS version 25.0 (SPSS Inc, Chicago, IL) and the statistical significance was defined as $\mathrm{P}<0.05$. Descriptive statistics were obtained for all variables of interest. The urinary concentrations of As species were not normally distributed with positive-skew profile and were logarithmically transformed using base-10 for analysis. All analysis was carried out using As species concentration in urine, both adjusted, or not, by SG. Analysis of variance (ANOVA) was performed to evaluate the effect of geographical location on urinary concentrations of As species. Principal component analysis (PCA) was performed with As species in urine and selected foods, drinks and nutrients in order to analyse the relationships among these variables and to identify the main dietary factors affecting As exposure. Due to the different units of measurement of variables, raw data was standardized to receive equal weight in PCA. Variables were standardised by subtracting the mean values from the raw data and dividing by the standard deviation. PCA was carried out using covariance matrix, with extraction of two components and varimax rotation with Kaiser normalization. Multiple

171 linear regression using stepwise method was performed to predict exposure to As from demographic, 172 clinical and dietary variables. 
174

175

176

177

178

179

180

181

182

183

184

\section{Results and Discussion}

A total of 89 participants $[n=42$ males $(47.2 \%), n=47$ females $(52.8 \%)]$ were included in the analysis, with ages ranging from $51.1 \mathrm{y}$ to $89.5 \mathrm{y}($ average $=65.9 \mathrm{y}$; median $=66.6 \mathrm{y})$. Demographic and clinical characteristics, including age, gender, weight, body mass index (BMI), smoking status and alcohol consumption are presented in Table 1 . BMI ranged from 20.9 to $43.9 \mathrm{~kg} / \mathrm{m}^{2}$ (average $=28.5 \mathrm{~kg} / \mathrm{m}^{2}$; median $\left.=27.7 \mathrm{~kg} / \mathrm{m}^{2}\right)$ and $26.9 \%$ of participants $(\mathrm{n}=24)$ had BMI $>30 \mathrm{~kg} / \mathrm{m}^{2}$. Forty participants $(44.9$ $\%)$ were current or previous smokers (44.9\%). Alcohol was consumed by 61 participants $(68.5 \%)$, with the mean consumption among consumers being $16.4 \mathrm{~g} /$ day (median: $4.81 \mathrm{~g} /$ day). All participants, with the exception of two, completed the food diary. Mean food and nutrient intake are presented in Table 2. The extent and spatial distribution of the participants in the study are shown in Figure 1.

The mean concentrations calculated for iAs, MMA, DMA and AsB in the CRMs were compared with the mean certified values in order to calculate percentage recoveries (Supplementary Material - Table S1). Recoveries of $108.3 \%, 87.2 \%, 94.7 \%$ and $86.9 \%$ resulted for iAs, MMA, DMA and AsB respectively for ClinChek ${ }^{\circledR}$ Control (level I). For Seronorm ${ }^{\mathrm{TM}}$ trace elements urine (lot 0511545), the reference values were expressed in terms of total As only. The recovery of total As was $97.6 \%$ and all experimental concentrations were within the acceptable range. The limit of detection was (LOD) for As speciation was $0.0067 \mu \mathrm{g} / \mathrm{L}$, as estimated from the DMA calibration.

The median concentration (5-95 ${ }^{\text {th }}$ percentiles) of $\mathrm{i}-\mathrm{As}$, MMA, DMA and AsB were $0.33(0.09-1.00)$ $\mu \mathrm{g} / \mathrm{L}, 0.32(0.10-0.92) \mu \mathrm{g} / \mathrm{L}, 1.92(0.58-7.53) \mu \mathrm{g} / \mathrm{L}$ and $2.28(0.13-62.46) \mu \mathrm{g} / \mathrm{L}$, respectively (Table 3). TMAO was below the detection limit in $\sim 70 \%$ of samples. No statistical differences were found between the two urine samples collected 6 months apart, in terms of AsB, iAs, MMA, DMA (paired t-test, $p$ > 0.05 , data not shown). Therefore, the $2^{\text {nd }}$ collected urine profile of each participant was considered for further analysis. Although women have shown more efficient methylation capacity than men in previous studies (Lindberg et al. 2008; Hudgens et al. 2016; Shen et al. 2016), gender was not a significant predictor of As exposure in the current study. 
As a naturally occurring element, the contribution of As exposure sources depends on the levels of As within soil, water and food. Drinking water or food originating from regions with high concentrations of As will result in a higher risk of adverse effects (Chappell et al. 2003; Wu et al. 2018). Results from a detailed geochemistry study conducted by The British Geological Surveys (BGS) indicate that the southern (South Armagh, Portaferry, Strangford and New Castle) and western (County Tyrone) regions of NI have high soil As concentrations (> $10 \mathrm{mg} / \mathrm{kg}$ ) (GSNI 2007). This geochemistry data has been previously used to investigate potential associations with chronic diseases. The relationship of nephrotoxicant elements (including As) and the prevalence of chronic kidney disease (CKD) was investigated by Jackson et al. (2016). The main association with CKD was found with elevated concentrations of the essential elements zinc and calcium in stream water (Jackson et al. 2016). A potential association has also been observed between incidence of stomach cancer and high levels of As in soils in the South Armagh area of NI (McKinley et al. 2013).

This current investigation of As exposure in Northern Ireland was performed in a population that was widely distributed throughout the country (Figure 1). The effect of geographical location was investigated by classifying participants according to their area of residence: Belfast $(n=21)$, West of Bann $(n=14)$, South Down \& Armagh $(n=11)$, East Derry \& North Antrim $(n=12)$, South Antrim (n $=18)$, North Down $(n=13)$. No differences were observed in terms of $\log _{10}$-transformed urinary concentrations of iAs, DMA or AsB across the various locations. Thus, the NI areas with high concentrations of As in soils were not reflected in terms of iAs exposure in its residents. MMA concentrations were lower in N. Down $\left(\log _{10}:-0.63\right)$ and in S. Antrim $\left(\log _{10}:-0.64\right)$ compared to Belfast $\left(\log _{10}:-0.37\right)$ and the West of the Bann $\left(\log _{10}:-0.34, p<0.05\right)$. A marginal difference $(p=0.053)$ was observed for the $\sum \mathrm{iAs}+\mathrm{MMA}+\mathrm{DMA}$, with similar profile to the one observed for MMA (Figure 2). The education level had no effect on As exposure in the investigated population.

Post-industrialized cities, such as Belfast and Derry, may be expected to have higher environmental pollutant burdens, including As (Shi et al 2012; Strosnider et al. 2017). However, previous reports show higher As levels in rural residents when compared to residents from urban communities ( Zailina et al. 
2014; Pang et al. 2016; Zhang et al. 2018). In the current study we found no difference in As exposure between metropolitan versus non-metropolitan areas (Greater Belfast versus other areas, or Greater Belfast + Greater Derry versus other areas) (Supplementary Material - Figure S1). Indeed, the results showed that residing in a city/urban area does not add additional sources of arsenic exposure as assayed through urinary As.

Considering the substantial number of food and nutrient variables, PCA was performed to evaluate the relationships between the dietary variables and to identify the main covariates of As exposure. Due to the different units of measurement (concentration, food/drink/nutrient intake), all variables were standardized to receive the same weight within the PCA. Two factors were generated from the PCA which accounted for $35.5 \%$ of the variability (Figure 3, Supplementary material - Table S2). Results from the PCA analysis showed that all As species clustered together, suggesting that the variability in urinary concentrations AsB and the inorganic species have a common source. The principal component 2 separates As species, with seafood consumption being more strongly related with As species, followed by alcohol consumption. Dairy products and tap water consumption were negatively related to As species, being diametrically opposite to the As species cluster on plots of PCA1 versus PCA2. Most of the nutrients (protein, energy, vitamins B1, B2, B3, B5, B6, B7, B9, selenium, carbohydrates) were not related to As species, being orthogonal in the PCA plot. Given that food intake was observed to be a better predictor of As exposure, as opposed to nutrient intake, subsequent multiple linear regression analysis were performed using foods as potential covariates (Figure 3). Nutrients were excluded from the regression analysis to avoid multicollinearity.

Multiple regression analysis showed that variation in urinary concentrations of iAs was explained mainly by dairy products (15.9\%), alcohol (8.9\%) and fortified cereals consumption $(4.0 \%)$. The total contribution of these covariates explained around $30 \%$ of iAs variability. Dairy product consumption showed a negative association with As exposure, suggesting that the higher the intake the lower the iAs concentration in urine. Since the urinary concentrations of inorganic As species are positively correlated with the urinary flow rate (Middleton et al., 2016), urinary concentrations adjusted for SG were used 
for PCA or multiple linear regression analysis. All analysis were carried out using both SG-normalized or non-normalized concentrations without changing significantly the results.

DMA is the main metabolite of iAs found in urine and accounts for approximately $60 \%-90 \%$ of $\sum \mathrm{iAs}+\mathrm{MMA}+\mathrm{DMA}$. Therefore, the variables which contributed significantly to the association in the multiple regression analysis were relatively similar for DMA and the $\sum \mathrm{iAs}+\mathrm{MMA}+\mathrm{DMA}$. Dairy product consumption was the main predictor of DMA and $\sum \mathrm{iAs}+\mathrm{MMA}+\mathrm{DMA}$, explaining approximately $15 \%$ of variation for each. Beside the apparent dilution effect of dairy products, seafood was a significant source of exposure accounting for $7-8 \%$, followed by a dilution effect of tap water which accounted for $6-7 \%$ of the total variability (Table 4$)$.

Seafood consumption, including both shellfish, oily fish and white fish, is known to be the main source of AsB (Signes-Pastor et al. 2017a; Jones et al. 2016). AsB in urine comes only from seafood consumption (Popowich et al. 2016) in contrast to DMA which is derived from As metabolism, seafood (Jones et al. 2016) and rice consumption (Punshon et al. 2018). In the present work, seafood was the main predictor of AsB, explaining $16 \%$ of the total variation is AsB urinary levels (Table 4). Milk consumption was considered a significant predictor in the current analysis, although it only explained 4.1\% of the total variation in AsB concentration. Overall, while milk and seafood consumption together explained $20 \%$ of the variation in $\mathrm{AsB}$, the majority of the variation remains unexplained. Although minor, when compared to AsB, seafood consumption was also a significant predictor of DMA, and the $\sum \mathrm{iAs}+\mathrm{MMA}+\mathrm{DMA}$, explaining approximately $7.5-8 \%$ of the total variation. Linear modelling showed that a daily increase of $100 \mathrm{~g}$ of seafood was associated with 6-fold increase in urinary DMA concentration (Table 4). Other variables such as age, weight, BMI, smoking status or education level were not found to be predictors of iAs, DMA, MMA or AsB.

The effect of alcohol on As exposure is not clear in the literature. Some authors have shown that alcohol consumption does not effect As speciation or As methylation capacities (Hopenhayn-Rich et al. 1996; Tseng et al. 2005; Huang et al. 2008), while others found that the consumption of alcoholic beverages is related to increased levels of iAs in urine (Saoudi et al. 2012, Mori et al. 2016). Wine has been 
previously reported as source of exposure by the regular use of arsenic as pesticide in vineyards in the past (Saoudi et al., 2012). We found here a positive association between alcohol consumption and urinary iAs (Figure 3, Table 4). This association suggests inhibition of As primary methylation, since a negative correlation was observed between alcohol consumption and MMA/iAs ratio (Spearman coefficient: -0.280 , p-value: 0.009$)$. The linear modellings showed that an increase of $10 \mathrm{~g} / \mathrm{day}$ in alcohol was associated with a $9.6 \%$ increase in urinary iAs concentration. These findings are consistent with those reported in a systematic review and meta-analysis by Shen et al. (2016) whereby primary methylation of iAs was 0.13-fold lower in alcohol drinkers compared to non-drinkers (Shen et al. 2016). Based on the present findings and on previous data (Hopenhayn-Rich et al. 1996; Tseng et al. 2005; Huang et al. 2008; Saoudi et al. 2012, Mori et al. 2016), we hypothesize that the alcohol effect on As exposure can only be observed when As exposure is relatively low and/or food is a dominant source. Beer consumption was positively associated with increased total As in urine in Japanese adults (Mori et al. 2016). Increased urinary concentrations of iAs+MMA+DMA were associated with higher wine consumption in a French cohort (Saoudi et al. 2012). Considering that similar effects are observed despite the alcoholic beverage (Saoudi et al. 2012, Mori et al. 2016), we suggest that the alcohol regulates As methylation. However, this effect is not observed at higher levels of As exposure (Hopenhayn-Rich et al. 1996; Tseng et al. 2005; Huang et al. 2008).

Drinking water is a relevant source of iAs in areas with high natural levels in public or private water supplies (Chappell et al. 2003; Kordas et al. 2016; Wei et al. 2014; Navoni et al. 2014; Diaz et al. 2015). In the city of Belfast, the concentration of iAs, DMA and TMAO in tap water ranged from 0.039-0.047 $\mu \mathrm{g} / \mathrm{L}, 0.027-0.031 \mu \mathrm{g} / \mathrm{L}$ and $0.050-0.057 \mu \mathrm{g} / \mathrm{L}$, respectively (Signes-Pastor et al. 2017b). These levels are very low compared to the parametric value of $10 \mu \mathrm{g} / \mathrm{L}$ for human consumption in the EU (CEU, 1998). Tap water consumption showed a moderate negative correlation with urine SG (Pearson correlation coefficient: $-0.462, \mathrm{p}<0.001$ ). Moreover, tap water intake showed a dilution effect on urinary As excretion, either adjusting or not the urinary concentrations by SG (Supplementary material - Figure S2). 
A similar dilution effect on As species excretion was observed for dairy products or milk consumption (Supplementary material - Figure S2). The average daily intake of dairy products reaches approximately $250 \mathrm{~g}$ (Table 2). Dairy products are generally low in iAs (Jackson et al. 2012; Sugár et al. 2013). As a result, low levels of As species can be expected in NI. In the linear models, an increase in dairy product consumption by 100 g per day was associated with a $26 \%$ decrease in iAs urinary concentration (Table 4). However, the dilution effect was not observed for the variable "water from drinks" which included water intake calculated from all drinks consumed including juices, infusions, dairy products and soft drinks. Similarly to tap water, a negative correlation was observed between "water from drinks" with the log-transformed iAs in urine normalized by SG. These findings corroborate the dilution effect of tap water on iAs levels in urine.

Results from the National Health and Nutrition Examination Survey (NHANES) and the US Department of Agriculture's Food Intakes Converted to Retail Commodities Database (FICRCD) showed that diet accounted for $11.5 \%$ of the variation in the $\sum \mathrm{iAs}+\mathrm{MMA}+\mathrm{DMA}$ (Davis et al. 2014). In the current study, diet explained $30 \%$ of the variation for the same urine As species. Unlike previous studies where ricebased products were reported to be a major cause of As exposure (Kordas et al. 2016; Wei et al. 2014) this was not evident in NI. Rice is not a food staple in NI (18), and its consumption in the studied population was very low (Table 2). The mean consumption of rice-based products was $20.2 \mathrm{~g} / \mathrm{day}$, which is equivalent to $6.0 \mathrm{~g}$ of dried grains/day (Table 2). Rice consumption did not show any significant association with urinary As species in the current population.

Despite the lack of a significant association between As exposure and nutrient intake in the current study, As hepatic metabolism has previously been shown to depend on the folate cycle and methionine cycle. The levels of SAM and glutathione, which are required for the serial As methylation and reduction reactions, respectively, are regulated by methionine and folate pathways while vitamin B6 and B12 are cofactors (Kurzius-Spencer et al. 2017). A previously randomized placebo-controlled trial showed that folate supplementation resulted in increased percentage of DMA and reduced percentages of MMA and iAs (Gamble et al. 2006). In NHANES 2003-2004, dietary folate, vitamin B6 and protein intake were 
correlated to lower percentage iAs and higher percentage DMA, in urine (Kurzius-Spencer et al. 2017). The high consumption of meat was also associated with higher percentage DMA in urine, probably due to the higher sources of protein and methionine, which are SAM precursors (Kordas et al. 2016).

The current study has some limitations. The results are based on small sample size of older adults which therefore limits the generalisability of the results. Due to the limited number of participants in this study, other clinical variables relating to liver and renal function could not be included in the models. The intra-individual variability on As kinetic disposition is likely to be higher in older adults than in young adults, due to the variable age-related reduction in renal and hepatic function, comorbidities and potential drug-arsenic interaction. Ageing is related to physiological reduced hepatic and renal clearance, but also age-related diseases (Hilmer 2008). An older population may be more representative for the assessment of residential area effect compared to younger adults who are more likely to travel or move (Wilding et al. 2018). The present study shows that $\mathrm{H}_{2} \mathrm{O}$, alcohol and seafood are important predictors of As levels in urine. It is, however, possible that other variables not evaluated in this work such as genetic polymorphisms related to As toxicokinetics may be important contributors and may increase the predictability of the regression models (Gribble et al. 2015).

\section{Conflict of interest}

All authors declare that there is no conflict of interest 


\section{References}

C.E.U. Council Directive 98/83/EC of November 1998 on the quality of water intended for human consumption, Official Journal European Community, May 12, 1998, pp. L330/32-L330/52, https://eur-

Chappell WR, Abernathy CO, Calderon RL, Thomas DJ (2003) Arsenic exposure and health effects V.

1. Chappell WR, Abernathy CO, Calderon RL, Thomas DJ, editor. Elsevier, Amsterdam, pp 3-103.

Davis MA, Gilbert-Diamond D, Karagas MR, Li Z, Moore JH, Williams SM, Frost, H. R (2014) A dietary-wide association study (DWAS) of environmental metal exposure in US children and adults. PLoS One 9:e104768. https://doi.org/10.1371/journal.pone.0104768

Davis MA, Signes-Pastor AJ, Argos M, Slaughter F, Pendergrast C, Punshon T, Gossai A, Ahsan H, Karagas MR (2017) Assessment of human dietary exposure to arsenic through rice. Sci Total Environ 586:1237-1244. https://doi.org/10.1016/j.scitotenv.2017.02.119

Diaz OP, Arcos R, Tapia Y, Pastene R, Velez D, Devesa V, Montoro R, Aguilera V, Becerra M (2015)

Estimation of arsenic intake from drinking water and food (raw and cooked) in a rural village of northern

Chile. Urine as a biomarker of recent exposure. Int J Environ Res Public Health 12:5614-5633.

371 https://doi.org/10.3390/ijerph120505614

372 Gamble MV, Liu X, Ahsan H, Pilsner J R, Ilievski V, Slavkovich V, Parvez F, Chen Y, Levy D, Factor373 Litvak P, Graziano JH (2006) Folate and arsenic metabolism: a double-blind, placebo-controlled folic 374 acid-supplementation trial in Bangladesh. Am J Clin Nutr 84:1093-1101. 375 https://doi.org/10.1093/ajcn/84.5.1093

376 Geological Survey Northern Ireland, GSNI (2007) Tellus project overview. 377 https://www.bgs.ac.uk/data/home.html?src=topNav Accessed on 25/09/18. 
378 Gribble M O, Voruganti VS, Cole SA, Haack K, Balakrishnan P, Laston SL, Tellez-Plaza M, 379 Francesconi KA, Goessler W, Umans JG. Thomas DC, Gilliland F, North KE, Franceschini N, Navas380 Acien A (2015) Linkage analysis of urine arsenic species patterns in the strong heart family study. 381 Toxicol Sci 148:89-100. https://doi.org/10.1093/toxsci/kfv164

382 Harrington KE, McGowan MJ, Kiely M, Robson PJ, Livingstone MB, Morrissey PA, Gibney MJ (2001) 383 Macronutrient intakes and food sources in Irish adults: findings of the North/South Ireland Food 384 Consumption Survey. Public Health Nutr 5A:1051-1060.

385 Hilmer SN (2008) ADME-tox issues for the elderly. Expert Opin Drug Metab Toxicol 4:1321-1331. 386 https://doi.org/10.1517/17425255.4.10.1321

387 Hopenhayn-Rich C, Biggs ML, Smith AH, Kalman DA, Moore LE (1996) Methylation study of a 388 population environmentally exposed to arsenic in drinking water. Environ Health Perspect 104:620389 628. https://doi.org/10.1289/ehp.96104620

390 Huang YK, Huang YL, Hsueh YM, Yang MH, Wu MM, Chen SY, Hsu LI, Chen CJ (2008) Arsenic 391 exposure, urinary arsenic speciation, and the incidence of urothelial carcinoma: a twelve-year follow392 up study. Cancer Causes Control 19:829-839. https://doi.org/10.1007/s10552-008-9146-5

393 Hudgens EE, Drobna Z, He B, Le XC, Styblo M, Rogers J, Thomas DJ (2016) Biological and behavioral 394 factors modify urinary arsenic metabolic profiles in a U.S. population. Environ Health 15:62. 395 https://doi.org/10.1186/s12940-016-0144-x.

396 IARC (2004) Monographs on the Evaluation of Carcinogenic Risk to Humans, volume 84; Some 397 Drinking-water Disinfectants and Contaminants, including Arsenic. World Health Organization, Lyon, 398 France.

399 IARC (2012), Arsenic, Metals, Fibres and Dust. Volume 100C. A review of human carcinogens. IARC 400 Monographs on the Evaluation of Carcinogenic Risk to Humans. World Health Organization, Lyon, 401 France. 
402

403

404

405

406

407

408

409

410

411

412

413

414

415

416

417

418

419

420

421

422

423

424

425

426

Jackson BP, Taylor VF, Punshon T, Cottingham KL (2012) Arsenic concentration and speciation in infant formulas and first foods. Pure Appl Chem 84:215-223. https://doi.org/10.1351/PAC-CON-11$09-17$

Jackson CE, McKinley JM, Ofterdinger U, Fogarty D, Atkinson PM, Palmer S (2016) Investigating relations between environmental toxins in Northern Irish soils and streams and Chronic Kidney Disease prevalence. Applied Geochemistry 75:236-246. https://doi.org/10.1016/j.apgeochem.2016.10.016

Jones MR, Tellez-Plaza M, Vaidya D, Grau M, Francesconi KA, Goessler W, Guallar E, Post WS, Kaufman JD, Navas-Acien A (2016) Estimation of inorganic arsenic exposure in populations with frequent seafood intake: evidence from MESA and NHANES. Am J Epidemiol 184:590-602. https://doi.org/10.1093/aje/kww097

Kordas K, Queirolo EI, Mañay N, Peregalli F, Hsiao PY, Lu Y, Vahter M (2016) Low-level arsenic exposure: Nutritional and dietary predictors in first-grade Uruguayan children. Environ Res 147:16-23. https://doi.org/10.1016/j.envres.2016.01.022

Kurzius-Spencer M, da Silva V, Thomson CA, Hartz V, Hsu CH, Burgess JL, O'Rourke MK, Harris RB (2017) Nutrients in one-carbon metabolism and urinary arsenic methylation in the National Health and Nutrition Examination Survey (NHANES) 2003-2004. Sci Total Environ 607-608:381-390. https://doi.org/10.1016/j.scitotenv.2017.07.019

Lindberg AL, Ekström EC, Nermell B, Rahman M, Lönnerdal B, Persson LA, Vahter M (2008) Gender and age differences in the metabolism of inorganic arsenic in a highly exposed population in Bangladesh. Environ Res 106:110-120. https://doi.org/10.1016/j.envres.2007.08.011

McKinley JM, Ofterdinger U, Young M, Barsby A, Gavin A (2013) Investigating local relationships between trace elements in soils and cancer data. Spatial Statistics 5:25-41. https://doi.org/10.1016/j.spasta.2013.05.001

Meharg AA, Raab A (2010) Getting to the bottom of arsenic standards and guidelines. Environ Sci Technol 44:4395-4399. https://doi.org/10.1021/es9034304 
Middleton DR, Watts MJ, Lark RM, Milne CJ, Polya DA (2016) Assessing urinary flow rate, creatinine, osmolality and other hydration adjustment methods for urinary biomonitoring using NHANES arsenic, iodine, lead and cadmium data. Environ Health 15:68. https://doi.org/ 10.1186/s12940-016-0152-x.

Mori M, Sato T, Yoshida HY, Ohira Y, Itou Y, Shimizu S (2016) Association of beer consumption with arsenic concentration in urine: a result from a cross-sectional study of the general Japanese population. Environ Health Prev Med 21:327-333. https://doi.org/10.1007/s12199-016-0533-3

Navas-Acien A, Francesconi KA, Silbergeld EK, Guallar E (2011) Seafood intake and urine concentrations of total arsenic, dimethylarsinate and arsenobetaine in the US population. Environ Res 111:110-118. https://doi.org/10.1016/j.envres.2010.10.009

Navoni JA, De Pietri D, Olmos V, Gimenez C, Bovi Mitre G, de Titto E, Villaamil Lepori EC (2014) Human health risk assessment with spatial analysis: study of a population chronically exposed to arsenic through drinking water from Argentina. Sci Total Environ 499:166-74. https://doi.org/10.1016/j.scitotenv.2014.08.058

Neville CE, Cruise SM, Burns F (2019) The Northern Ireland Cohort for the Longitudinal Study of Ageing (NICOLA). Encyclopedia of Gerontology and Geriatrics, In press, May

Nutritics (2018) Research Edition (v5.02) [Computer software]. Dublin. Retrieved from www.nutritics.com. Nutritics, Research Edition, v5.02, Dublin.

Ouypornkochagorn S, Feldmann J (2010) Dermal uptake of arsenic through human skin depends strongly on its speciation. Environ Sci Technol 44:3972-3978. https://doi.org/10.1021/es903667y.

Pang Y, Peng RD, Jones MR, Francesconi KA, Goessler W, Howard BV, Umans JG, Best LG, Guallar E, Post WS, Kaufman JD, Vaidya D, Navas-Acien A (2016) Metal mixtures in urban and rural populations in the US: The Multi-Ethnic Study of Atherosclerosis and the Strong Heart Study. Environ Res 147:356-364. https://doi.org/10.1016/j.envres.2016.02.032

Popowich A, Zhang Q, Le XC (2016) Arsenobetaine: the ongoing mystery. National Science Review 3:451-458. https://doi.org/10.1093/nsr/nww061 
452 Punshon T, Carey AM, Ricachenevsky FK, Meharg AA (2018) Elemental distribution in developing 453 rice grains and the effect of flag-leaf arsenate exposure. Environ Exp Bot 149:51-58. 454 https://doi.org/10.1016/j.envexpbot.2018.02.007

455 Saoudi A, Zeghnoun A, Bidondo ML, Garnier R, Cirimele V, Persoons R, Fréry N (2012) Urinary 456 arsenic levels in the French adult population: The French National Nutrition and Health Study, 2006457 2007. Sci Total Environ 433:206-215. https://doi.org/10.1016/j.scitotenv.2012.06.053

458 Shen H, Niu Q, Xu M, Rui D, Xu S, Feng G, Ding Y, Li S, Jing M (2016) Factors Affecting Arsenic 459 Methylation in Arsenic-Exposed Humans: A Systematic Review and Meta-Analysis. Int J Environ Res 460 Public Health 13:205. https://doi.org/10.3390/ijerph13020205.

461 Shi G, Chen Z, Teng J, Bi C, Zhou D, Sun C, Li Y, Xu S (2012) Fluxes, variability and sources of 462 cadmium, lead, arsenic and mercury in dry atmospheric depositions in urban, suburban and rural areas. 463 Environ Res 113:28-32. https://doi.org/10.1016/j.envres.2012.01.001

464 Signes-Pastor AJ, Carey M, Vioque J, Navarrete-Muñoz EM, Rodríguez-Dehli C, Tardón A, Begoña465 Zubero M, Santa-Marina L, Vrijheid M, Casas M, Llop S, Gonzalez-Palacios S, Meharg AA (2017c) 466 Urinary Arsenic Speciation in Children and Pregnant Women from Spain. Expo Health 9:105-111. 467 https://doi.org/10.1007/s12403-016-0225-7 M, Riaño-Galán I, Tardón A, Llop S, Amorós R, Amiano P, Bilbao JR, Karagas MR, Meharg AA (2017a). Concentrations of urinary arsenic species in relation to rice and seafood consumption among children living in Spain. Environ Res 159:69-75. https://doi.org/10.1016/j.envres.2017.07.046.

472 Signes-Pastor AJ, Woodside JV, McMullan P, Mullan K, Carey M, Karagas MR, Meharg AA (2017b)

473 Levels of infants' urinary arsenic metabolites related to formula feeding and weaning with rice products 474 exceeding the EU inorganic arsenic standard. PLoS One 12:e0176923. 475 https://doi.org/10.1371/journal.pone.0176923. 
476 Strosnider H, Kennedy C, Monti M, Yip F (2017) Rural and Urban Differences in Air Quality, 2008477 2012, and Community Drinking Water Quality, 2010-2015 - United States. Center for Disease Control 478 and Prevention, MMWR Surveill Summ 66:1-10. https://doi.org/10.15585/mmwr.ss6613a1

479 Subhani M, Mustafa I, Alamdar A, Katsoyiannis IA, Ali N, Huang Q, Peng S, Shen H, Eqani SA. (2015) 480 Arsenic levels from different land-use settings in Pakistan: Bio-accumulation and estimation of potential 481 human health risk via dust exposure. Ecotoxicol Environ Saf 115:187-194. 482 https://doi.org/10.1016/j.ecoenv.2015.02.019.

483 Sugár E, Tatár E, Záray G, Mihucz VG (2013) Relationship between arsenic content of food and water applied for food processing. Food Chem Toxicol 62:601-608. https://doi.org/10.1016/j.fct.2013.09.028

Tseng CH, Huang YK, Huang YL, Chung CJ, Yang MH, Chen CJ, Hsueh YM (2005) Arsenic exposure, urinary arsenic speciation, and peripheral vascular disease in blackfoot disease-hyperendemic villages in Taiwan. Toxicol Appl Pharmacol 206:299-308. https://doi.org/10.1016/j.taap.2004.11.022

Wardrop NA, Le Blond JS (2015) Assessing correlations between geological hazards and health 489 outcomes: Addressing complexity in medical geology. Environ Int 84:90-93. https://doi.org/10.1016/j.envint.2015.07.016

Wei Y, Zhu J, Nguyen A (2014) Rice consumption and urinary concentrations of arsenic in US adults. Int J Environ Health Res 24:459-470. https://doi.org/10.1080/09603123.2013.857393

WHO (2001) Environmental Health Criteria 224 - Arsenic and Arsenic compounds, Geneva: International Program on Chemical Safety, 501 p.

Wilding S, Martin D, Moon G (2018) Place and preference effects on the association between mental health and internal migration within Great Britain. Health Place 52:180-187. https://doi.org/10.1016/j.healthplace.2018.06.008

Williams PN, Islam MR, Adomako EE, Raab A, Hossain SA, Zhu YG, Feldmann J, Meharg AA (2006) Increase in rice grain arsenic for regions of Bangladesh irrigating paddies with elevated arsenic in groundwaters. Environ Sci Technol 40:4903-8. https://doi.org/10.1021/es060222i 
501 Wu F, Chi L, Ru H, Parvez F, Slavkovich V, Eunus M, Ahmed A, Islam T, Rakibuz-Zaman M, Hasan 502 R, Sarwar G, Graziano JH, Ahsan H, Lu K, Chen Y (2018) Arsenic Exposure from Drinking Water 503 and Urinary Metabolomics: Associations and Long-Term Reproducibility in Bangladesh Adults.

504 Environ Health Perspect 126:017005. https://doi.org/10.1289/EHP1992.

505 Xu S, Zheng N, Liu J, Wang Y, Chang S (2013) Geochemistry and health risk assessment of arsenic 506 exposure to street dust in the zinc smelting district, Northeast China. Environ Geochem Health 35:89507 99. https://doi.org/10.1007/s10653-012-9463-1.

508 Zailina H, Najibah H, Aiezzati AN, Praveena SM, Patimah I (2014) Comparison of the health 509 implications on the use of As and Cd contaminated water supply between urban and rural communities. 510 Biomed Res Int 2014:797603. https://doi.org/10.1155/2014/797603

511 Zhang X, Wang B, Cui X, Lin C, Liu X, Ma J (2018) Total arsenic concentrations in Chinese children's 512 urine by different geographic locations, ages, and genders. Environ Geochem Health 40:1027-1036. 513 https://doi.org/10.1007/s10653-017-9963-0

517 Table 1. Demographic and clinical characteristics of study participants $(n=89)$.

\section{Characteristics}

Gender

Male: $42(47.2 \%)$

Female: $47(52.8 \%)$

\begin{tabular}{lc}
\hline Age (years) & $65.9(51.1-89.5)$ \\
& $66.6(59-72.7)$ \\
\hline Weight (kg) & $77.3(53.8-130)$ \\
& $75.6(66.2-86.4)$ \\
\hline
\end{tabular}




\begin{tabular}{ll}
\hline BMI $\left(\mathbf{k g} / \mathbf{m}^{2}\right)$ & $28.5(20.9-43.9)$ \\
& $27.7(25.5-30.4)$ \\
& $<25 \mathrm{~kg} / \mathrm{m}^{2}: 18(20.2 \%)$ \\
& $\geq 25$ and $<30 \mathrm{~kg} / \mathrm{m}^{2}: 47(52.8 \%)$ \\
& $\geq 30 \mathrm{~kg} / \mathrm{m}^{2}: 24(26.9 \%)$ \\
\hline SMI status & Current or previous: $40(44.9 \%)$ \\
& Never: $49(55.1 \%)$ \\
\hline Current: $61(68.5 \%)$ & Ex: $12(13.5 \%)$ \\
& Never: $16(17.9 \%)$ \\
& Average (min-max) consumption among \\
& users: $16.4 \mathrm{~g} /$ day $(0-109.02 \mathrm{~g} / \mathrm{day})$ \\
\hline Education level & No education/primary education: $11(12.3 \%)$ \\
& Secondary education: $37(41.6 \%)$ \\
\hline & \\
& \\
& \\
& \\
\hline &
\end{tabular}

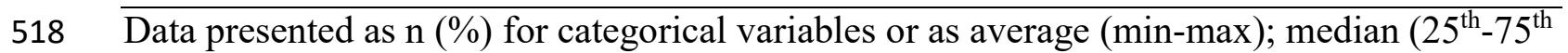
519 percentiles) for continuous variables

521 Table 2. Intake of selected food and nutrients as reported in 4-day food diaries $(\mathrm{n}=87)$.

\begin{tabular}{lccc}
\hline Characteristics & Range & Mean $\mathbf{( 9 5 \%}$ CI) & Median $\left(5-95^{\text {th }}\right.$ Percentile) \\
\hline Food and drinks & & & \\
Tap water (L/day) & $0-2.85$ & $1.11(1.00-1.21)$ & $1.08(0.46-1.93)$ \\
Alcohol (g/day) & $0-109$ & $16.4(11.1-21.7)$ & $4.8(0-75.5)$ \\
Meat $^{\mathrm{b}}$ (g/day) & $0-406.7$ & $127.2(110.5-143.9)$ & $128.5(6.3-268.5)$ \\
Fish and seafood $^{\mathrm{c}}$ (g/day) & $0-191$ & $28.6(20.2-36.9)$ & $21(0-97)$ \\
Poultry $^{\mathrm{d}}$ (g/day) & $0-281$ & $44.0(33.0-54.9)$ & $75.5(52.5-124.6)$ \\
Rice $^{\mathrm{e}}$ & & & \\
$\quad$ Rice-based products (g/day) & $0-158$ & $20.2(12.9-27.6)$ & $0(0-93)$ \\
$\quad$ Rice (g of dried grains/day) & $0-52.1$ & $6.0(3.72-8.28)$ & $0(0-29.1)$ \\
Potatoes (g/day) & $0-557.5$ & $129.7(106.8-152.6)$ & $103.7(0-319.9)$ \\
Eggs (g/day) & $0-145.0$ & $27.6(21.1-34.1)$ & $18.8(0-81.9)$ \\
Dairy & (g/day) & & \\
$\quad$ Total dairy products & $0-658.7$ & $249.3(218.7-280.0)$ & $233.9(30.3-497.8)$ \\
$\quad$ Milk & $0-641.2$ & $180.5(151.9-209.0)$ & $164.5(0-394.5)$ \\
$\quad$ Cheese and yogurts & $0-240.0$ & $44.7(34.1-55.3)$ & $26.3(0-143.1)$
\end{tabular}


Cream products

Cheese, yogurts and cream

Eggs and dairy (g/day)

Whole grains ${ }^{\mathrm{g}}$ (g/day)

Legumes $^{\text {h }}$ (g/day)

Seeds and nuts ${ }^{\mathrm{i}}$ (g/day)

Dark leafy vegetables ${ }^{j}$ (g/day)

Fortified cereals $^{\mathrm{k}}$ (g/day)

\section{Nutrients}

Energy (kcal/day)

Protein (g/day)

Carbohydrate (g/day)

Fat (g/day)

Thiamine (B1, mg/day)

Riboflavin (B2, mg/day)

Niacin (B3, mg/day)

Pantothenate (B5, mg/day)

Pyridoxine (B6, mg/day)

Biotine (B7, mg/day)

Folates (B9) ( $\mu \mathrm{g} /$ day)

Total folates

Dietary Folate Equivalent (DFE)

Natural folates

Synthetic folates

Cobalamine (B12, $\mu \mathrm{g} /$ day)

Methionine (mg/day)

Cysteine (mg/day)

Selenium $(\mu \mathrm{g} /$ day $)$
$0-217.8$

$0-261.3$

$0-686.2$

$0-510.0$

$0-165.0$

0-98.0

$0-105.0$

$0-285.0$

$\begin{array}{cc}980-3450 & 1948(1837-2058) \\ 32.3-159.7 & 79.9(74.8-84.9) \\ 65.0-389.6 & 210.2(197.6-222.7) \\ 36.2-160.1 & 76.2(70.9-81.5) \\ 0.5-3.4 & 1.7(1.5-1.8) \\ 0.6-3.9 & 1.8(1.7-2.0) \\ 11.4-108.1 & 37.7(34.7-40.7) \\ 1.5-18.2 & 6.2(5.7-6.7) \\ 0.4-8.4 & 2.1(1.9-2.4) \\ 12.3-85.9 & 43.8(40.6-47.1)\end{array}$

$105.0-797.8$

$105.0-857.8$

$267.8(243-1-292.4)$

71.7-573.7

279.8 (251.7-307.9)

$0-348.0$

$239.0(218.5-259.5)$

$0.3-39.6$

$0-2490.6$

$0-939.6$

$14.5-153.3$
$27.2(15.8-38.6)$

$5.5(4.5-6.6)$

$24.1(17.0-31.3)$

$68.9(56.2-81.5)$

6.9 (246.1-307.7)

$82.8(66.4-99.1)$

$6.2(3.0-9.3)$

$19.2(13.8-24.6)$

$15.9(7.8-24.0)$

$120.2(46.6-193.8)$

70.4 (41.1-99.7)

$45.1(40.6-49.5)$
$14.6(0-75.1)$

$52.6(2.1-176.8)$

$271.8(61.7-521.0)$

$68.0(0-213.0)$

$13.3(0-97.9)$

$0(0-28.2)$

$11.0(0-74.0)$

$0(0-58.5)$

\author{
1883 (1248-2931) \\ 75.5 (52.5-124.6) \\ $200.1(133.5-319.9)$ \\ $75.7(38.5-125.8)$ \\ $1.6(0.9-2.8)$ \\ $1.8(0.9-3.1)$ \\ $35.1(21.2-57.6)$ \\ $5.8(3.8-9.5)$ \\ $1.8(1.1-3.9)$ \\ $43.0(22.6-70.1)$
}

$242.5(145.1-508.7)$

$260.0(148.5-499.7)$

$216.5(139.2-430.1)$

$0(0-110.8)$

$4.9(1.5-9.7)$

$16.8(0-428.3)$

$23.9(0-275.5)$

41.3 (18.9-78.5)

a Water from the tap for drinking, used to prepare powdered drinks or infusions, boiled or not.

${ }^{\text {b}}$ Red meat, poultry, fish and seafood

'Fatty fish (salmon, sardines, trout, mackerel, tuna, anchovies), white fish (cod, haddock, hake, monkfish, seabass, whiting, sole),

shellfish (scallops, prawns, crayfish, mussels, squid, lobster)

${ }^{\mathrm{d} C h i c k e n ~ a n d ~ t u r k e y ~}$

eWhite and brown rice, boiled, steamed or in rice-based products (noodles, rice cakes, breakfast cereal flakes, pudding);

${ }^{f}$ Milk (whole, semi skimmed or skimmed) from cow, goat or sheep, cheeses, yogurts, creams (crème fraiche, sour cream, double cream, whipping cream and ice cream)

${ }^{\mathrm{g}}$ Brown rice, wholewheat, barley, millet, quinoa, oats, popcorn, whole rye, wheat berry

hLegumes: beans, chickpeas, green peas and lentils

iSunflower seeds, cashew nuts, pistachios, peanuts, almonds, pine nuts, coconut, walnuts, pecan nuts, Brazil nuts, quinoa, flax seed

almonds

${ }^{\mathrm{j}}$ Fortified cereals (breakfast cereals, breads, cakes fortified with B vitamins)

kDark, leafy vegetables: kale, Brussel's sprouts, spinach, rocket, broccoli, mustard

Table 3. Urinary concentration of arsenic (As) species in the study population $(n=89)$, with and

without specific gravity normalization

\begin{tabular}{lcccccc}
\hline & iAs & MMA & DMA & AsB & Total As & $\begin{array}{c}\sum \text { iAs+MMA } \\
\text { +DMA }\end{array}$ \\
& & & & & & \\
\hline \multicolumn{2}{l}{ Urinary concentrations $(\boldsymbol{\mu g} / \mathbf{L})$} \\
Mean & 0.42 & 0.40 & 2.78 & 12.01 & 15.66 & 3.60 \\
$(\mathbf{9 5 \%} \mathbf{C I})$ & $(0.35-0.48)$ & $(0.34-0.46)$ & $(2.24-3.32)$ & $(7.16-16.9)$ & $(10.5-20.8)$ & $(2.98-4.21)$
\end{tabular}




\begin{tabular}{|c|c|c|c|c|c|c|}
\hline Median $\left(5-95^{\text {th }}\right.$ & $0.33(0.09-$ & $0.32(0.10-$ & $1.92(0.58-$ & $2.28(0.13-$ & $5.44(1.33-$ & $2.57(0.80-$ \\
\hline percentiles) & $1.00)$ & $0.92)$ & $7.53)$ & $62.46)$ & $69.53)$ & $9.46)$ \\
\hline Range & $0.07-1.68$ & $0.06-1.36$ & $0.26-14.64$ & $0.05-127.31$ & $0.64-135.23$ & $0.45-14.85$ \\
\hline \multicolumn{7}{|c|}{ Urinary concentrations, specific gravity normalized ( $\mu \mathrm{g} / L)$} \\
\hline Mean $(95 \%$ & $0.41(0.35-$ & $0.39(0.34-$ & $2.73(2.21-$ & $11.78(7.04-$ & $15.37(10.37-$ & $3.54(2.93-$ \\
\hline CI) & $0.48)$ & $0.45)$ & $3.26)$ & 16.52) & 20.37) & 4.14) \\
\hline Median $\left(5-95^{\text {th }}\right.$ & $0.32(0.08-$ & $0.31(0.10-$ & $1.90(0.58-$ & $2.24(0.13-$ & $5.33(1.32-$ & $2.51(0.79-$ \\
\hline percentiles) & $0.98)$ & $0.91)$ & $7.35)$ & 61.19) & 67.91) & $9.23)$ \\
\hline Range & $0.07-1.64$ & $0.06-1.33$ & $0.26-14.49$ & $0.05-124.56$ & $0.64-132.32$ & $0.45-14.71$ \\
\hline
\end{tabular}

538 iAs: inorganic As; MMA: monomethylarsonic acid; DMA: dimethylarsinic acid; AsB: arsenobetaine, Total As:

539 sum of all species in urine, $\sum \mathrm{iAs}+\mathrm{MMA}+\mathrm{DMA}$ : sum of iAs, MMA and DMA concentrations in urine; $95 \% \mathrm{CI}$ :

$54095 \%$ confidence interval

549 Table 4. Multiple regression analysis showing the contributors to urinary arsenic (As) species in terms

550 of demographic, clinical and dietary variables (nutrients excluded).

\begin{tabular}{lccccc}
\hline Variable & iAs & MMA & DMA & iAs+MMA & AsB \\
& & & & + DMA & \\
\hline Dairy products & $16.0 \% * * *$ & - & $14.8 \% * *$ & $15.7 \% * *$ \\
Alcohol & $9.0 \% * * *$ & - & - & - & - \\
\hline
\end{tabular}




\begin{tabular}{|c|c|c|c|c|c|}
\hline Fortified cereals & $4.0 \% *$ & - & - & - & - \\
\hline Tap water & - & $15.3 \% * * *$ & $5.8 \% *$ & $6.9 \% * *$ & - \\
\hline Milk & - & $4.5 \% *$ & & & $4.1 \% *$ \\
\hline Seafood & - & - & $7.5 \% * *$ & $7.8 \% * *$ & $16.0 \% * * *$ \\
\hline Poultry & - & - & $3.5 \% *$ & - & - \\
\hline Total & $29.0 \%$ & $19.8 \%$ & $31.6 \%$ & $30.4 \%$ & $20.1 \%$ \\
\hline \multicolumn{6}{|l|}{ contribution } \\
\hline $\mathrm{P}$-value ${ }^{\mathrm{a}}$ & $<0.001$ & $<0.001$ & $<0.001$ & $<0.001$ & $<0.001$ \\
\hline
\end{tabular}

551 Urinary As species variables were log-transformed and normalized by specific gravity.

$552 \log [\mathrm{iAs}]=-0.366-0.001 \times$ Dairy products $(\mathrm{g} / \mathrm{d})+0.004 \times$ Alcohol $(\mathrm{g} / \mathrm{d})+0.002 \times$ Fortified cereals $553(\mathrm{~g} / \mathrm{d})$

$554 \log [\mathrm{MMA}]=-0.161-0.222 \times \operatorname{Tap}$ water $(\mathrm{L} / \mathrm{d})-0.000461 \times \operatorname{Milk}(\mathrm{g} / \mathrm{d})$

$555 \log [D M A]=0.651-0.001 \times$ Dairy products $(g / d)+0.003 \times \operatorname{Seafood}(g / d)-0.168 \times$ Tap water $(L / d)-$

$5560.001 \times$ Poultry $(\mathrm{g} / \mathrm{d})$

$557 \log [\mathrm{iAs}+\mathrm{MMA}+\mathrm{DMA}]=0.736-0.001 \times$ Dairy $\operatorname{products}(\mathrm{g} / \mathrm{d})+0.002 * \operatorname{Seafood}(\mathrm{g} / \mathrm{d})-0.172 \times$ Tap $558 \quad$ water $(\mathrm{L} / \mathrm{d})$

$559 \log [\mathrm{AsB}]=0.432+0.008 \times \operatorname{Seafood}(\mathrm{g} / \mathrm{d})-0.001 \times \operatorname{Milk}(\mathrm{g} / \mathrm{d})$

$560 * \mathrm{P}<.05, * * \mathrm{P}<0.01, * * * \mathrm{P}<0.001$

$561 \quad{ }^{\text {ap}} \mathrm{P}$-value for the $\mathrm{F}$ test 